\title{
PENGARUH KOMUNIKASI, PELATIHAN DAN MOTIVASI TERHADAP KINERJA PEGAWAI BNNP BENGKULU MENURUT PRESPEKTIF ISLAM
}

\author{
Ratih Komala Dewi \\ IAIN Curup \\ e-mail: ratih.komala@iaincurup.ac.id
}

\begin{abstract}
This study describes the influence of communication, training, and motivation on employee performance in the National Narcotics Board in Bengkulu Province. The method of data collection in research subjects was determined using purposive sampling, namely all employees of the National Narcotics Board in Bengkulu Province 89 people who were respondents in. The qualitative method of data analysis is done by processing SPSS software data with F test statistics and t test statistics and drawing conclusions and verifying data. The results of this study indicate that communication, training and motivation have a simultaneously significant influence on the performance of the National Narcotics Board in Bengkulu Province. At the National Narcotics Board in Bengkulu Province, communication as a medium for delivering information is very important to support the task of the National Narcotics Agency as a vocal point to make efforts to prevent, eradicate the use and illicit circulation of drugs. In addition, the training provided by the National Narcotics Board in Bengkulu Province greatly supports improved performance so that employees can work more optimally. Furthermore, the motivation given by superiors to employees of the National Narcotics Board in Bengkulu Province also had a positive impact on employee performance.
\end{abstract}

Keywords: employee performance, communication, training, motivation

Abstrak: Penelitian ini mendeskripsikan pengaruh komunikasi, pelatihan, dan motivasi terhadap kinerja karyawan di Badan Narkotika Nasional Provinsi Bengkulu. Metode pengumpulan data pada subjek penelitian ditentukan dengan menggunakan purposive sampling, yaitu seluruh pegawai Badan Narkotika Nasional Provinsi Bengkulu 89 orang yang menjadi responden. Metode kualitatif analisis data dilakukan dengan mengolah data software SPSS dengan statistik uji $F$ dan statistik uji $t$ dan menarik kesimpulan dan verifikasi data. Hasil penelitian ini menunjukkan bahwa komunikasi, pelatihan dan motivasi memiliki pengaruh signifikan secara signifikan terhadap kinerja Badan Narkotika Nasional Provinsi Bengkulu. Pada Badan Narkotika Provinsi Bengkulu, komunikasi sebagai media penyampaian informasi sangat penting untuk mendukung tugas Badan Narkotika Nasional sebagai vocal point dengan mengindahkan kaidah Islami untuk melakukan upaya pencegahan, pemberantasan penggunaan dan peredaran gelap narkoba. Selain itu, pelatihan yang diberikan oleh Badan Narkotika Nasional Provinsi Bengkulu dengan menjunjung tinggi etika dan norma guna mendukung peningkatan kinerja sehingga karyawan dapat bekerja lebih optimal. Selanjutnya, motivasi Islami yang diberikan oleh atasan kepada pegawai Badan Narkotika Provinsi Bengkulu juga berdampak positif terhadap kinerja karyawan.

Kata kunci: kinerja karyawan, komunikasi, pelatihan, motivasi

\section{A. PENDAHULUAN}

Badan Narkotika Nasional

Provinsi Bengkulu merupakan salah satu instansi vertikal yang melaksanakan tugas, fungsi dan wewenang BNN dalam wilayah Provinsi yang lebih lanjut diatur dalam Peraturan Kepala BNN Nomor 6 Tahun 2015 yang merupakan perbaruan atas Peraturan Kepala BNN Nomor 3

Tahun 2015
Dessler

dan

Counter mengemukakan salah satu cara untuk mengembangkan kinerja yang dimiliki oleh karyawan di perusahaan yaitu dengan mengadakan program pelatihan yang diterapkan dan dibuat sesuai kebutuhan dari perusahaan. Pelatihan adalah proses pembelajaran keterampilan 
dasar yang dibutuhkan oleh karyawan baru untuk melaksanakan pekerjaan. ${ }^{1}$

Allah SWT berfirman dalam Al Qur'an $^{2}$ Surat Al-Ahqaaf ayat 19 yang berbunyi :
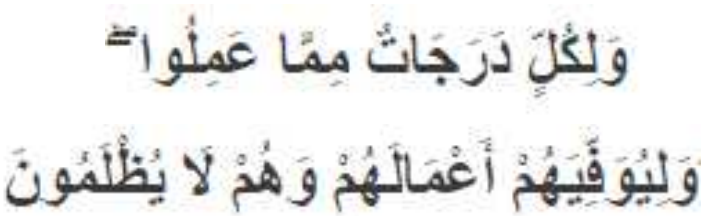

Artinya : "Dan bagi masing-masing mereka derajat menurut apa yang telah mereka kerjakan dan agar Allah mencukupkan bagi mereka (balasan) pekerjaanpekerjaan mereka sedang mereka tiada dirugikan." (Q.S. Surat Al-Ahqaaf :19)

Berdasarkan ayat diatas dijelaskan bahwa setiap segala sesuatu yang dikerjakan akan diberikan balasan tanpa ada yang dirugikan. Dengan kata lain apabila seorang karyawan melaksanakan tugas dan tanggung jawab yang disemban sesuai dengan aturan maka akan menunjukkan kinerja yang baik bagi perusahaan.

Dalam menjalankan tugas, fungsi dan wewenang tersebut, Badan Narkotika Nasional Provinsi Bengkulu selalu mendapatkan pelatihan-pelatihan pada masing-masing bidang tugas guna meningkatkan kinerja para pegawai. Para pegawai pada bidang tugas tertentu

1 Dessler, Manajemen Sumber Daya Manusia. Alih bahasa: Eli Tanya. Penyunting Bahasa: Budi Supriyanto, Indeks, Jakarta, hlm. 27

${ }^{2}$ Departemen Agama RI. Al-Qur'an dan terjemahan. Jakarta. 2010, Surat biasanya akan di undang untuk mengikuti pelatihan dari Badan Nakotika Nasional Republik Indonesia. Beberapa pelatihan yaitu pelatihan bagi aplikator Aplikasi Sistem Informasi Narkoba (SIN), pelatihan bagi aplikator Aplikasi Sistem Informasi Rehabilitasi Narkoba (SIRENA), dan bebagai pelatihan kepegawaian, serta pelatihan lainnya.

Berikut hasil tabulasi data pelatihan yang dilakukan oleh para pegawai Badan Narkotika Nasional Provinsi Bengkulu Tahun 2018 yang di visualisasikan sebagai berikut:

\section{Gambar 1 Data Pelatihan Pegawai BNN Provinsi Bengkulu Tahun 2018}

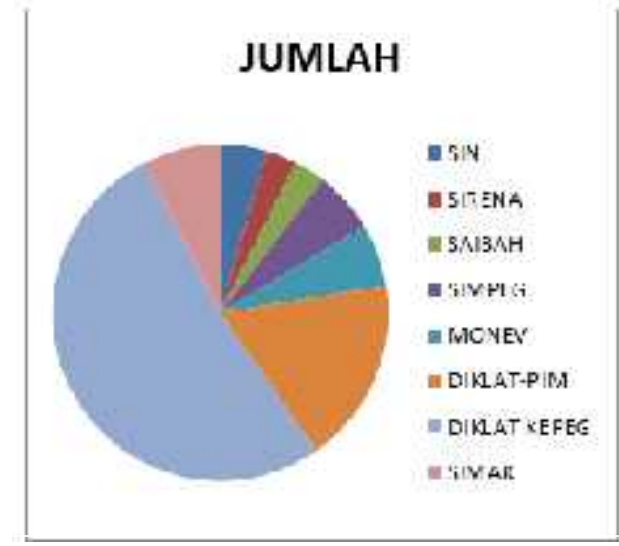

Sumber : Data Kepegawaian BNN Provinsi Bengkulu 2018

Berdasarkan tabulasi data diatas diperoleh bahwa paling dominan yang melakukan diklat kepegawaian jikan di tinjau dari jumlah pegawai yang dilatih jika di banding dengan pelatihan aplikator beberapa aplikasi yang di pakai ada Badan Narkotika Nasional Provinsi Bengkulu Tahun 2018. Hal ini dikarenakan aplikator suatu aplikasi 
biasanya hanya 1-3 orang saja setiap aplikasi dan biasanya aplikator tersebut menerima pelatihan langsung dari Badan Narkotika Nasional Republik Indonesia.

Dalam kesempatan yang sama, Dessler ${ }^{3}$ menyatakan pelatihan mempunyai hubungan yang erat terhadap motivasi. Pemberian pelatihan mempengaruhi motivasi pegawai, karena setelah mengikuti pelatihan pegawai mempunyai keterampilan (skill) dan terampil dalam mengerjakan tugas yang diberikan instansi dengan bobot tugas yang lebih berat, sehingga sikap pegawai lebih baik dalam menerima tugas dan bersemangat dalam mengerjakan tugas.

Septiana ${ }^{4}$ menyatakan bahwa motivasi serta pemberian pengetahuan merupakan nilai - nilai dasar yang mesti diinternalisasi kepada seluruh pegawai agar timbul kesadarapan para pegawai tersebut bahwa mereka merupakan tenaga-tenaga kerja ahli dan terampil yang menajdi asset perusahaan dan dibutuhkan untuk kemajuan perusahaan. Selanjutnya langkah dalam efektivitas dan efisiensi para pegawai dapat dilakukan melalui peningkatan pengetahuan dan keterampilan pegawai misalnya berupa program pendidikan dan latihan (diklat), sedangkan pada sisi lain

\footnotetext{
${ }^{3}$ Ibid,.

4 Septiana, Manajemen Pemasaran, (Bandung: CV. Setia Budi, 2018), hlm. 54
}

peningkatan sikap karyawan terhadap pekerjaan serta tugas-tugasnya dapat dilakukan dengan usaha memotivasi para karyawan.

Pada Badan Narkotika Nasional Provinsi Bengkulu, motivasi terus diberikan kepada para pegawai dalam melakukan pengembangan kompetensi guna meningkatkan kinerja. Salah satu upaya pemberian motivasi dengan mengadakan family gathering sebagai media refreshing bersama dan menimbulkan suasana kekeluargaan.

Family gathering yang diadakan oleh Badan Narkotika Nasional satu kali setiap tahun yang di isi dengan games untuk meningkatkan kinerja kerja tim, kecepatan, ketepatan dan kepedulian terhadap sesama pegawai.

Hardjana, A.M ${ }^{5}$ menjelaskan bahwa komunikasi adalah proses penyampaian pikiran atau perasaan oleh seseorang kepada orang lain dengan menggunakan symbol-simbol yang dapat dipahami kedua belah pihak dalam situasi yang tertentu komunikasi menggunakan media tertentu untuk merubah sikap seorang atau sejumlah orang sehingga ada efek tertentu yang diharapkan. Komunikasi tersebut dapat menyampaikan informasi secara langsung

\footnotetext{
${ }^{5}$ Hardjana, A.M, Manajemen Sumber Daya Manusia, (Bandung: CV. Taraluya Pustaka, 2007), hlm. 38
} 
dan cepat. Oleh sebab itu komunikasi amat sangat dibutuhkan terutama dalam bidang pekerjaan karena dapat menjadikan hasil kerja lebih optimal.

Komunikasi merupakan salah satu hal yang sangat penting sebagai proses saling memberi informasi dalam melaksakan tugas di lingkungan Badan Narkotika Nasional Provinsi Bengkulu terutama pada bidang Pencegahan dan Pemberdayaan Masyarakat. Adapun tugas pokok dari Bidang Pencegahan dan Pemberdayaan Masyarakat tersebut yaitu memberikan diseminasi kepada masyarakat mengenai dampak dan bahaya narkoba yang dilakukan secara persuatif. Dalam hal ini komunikasi dua arah sangatlah diharapkan agar terciptanya suasana yang kondusif agar informasi yang beri dan diterima tidaklah bias.

Berdasarkan pra penelitian atau pengamatan awal, terdapat fenomena yang ada serta dilengkapi dengan data dan fakta di Badan Narkotika Nasional Provinsi Bengkulu yang memiliki Oleh karena itu, peneliti tertarik untuk mengangkat penelitian dengan judul "Pengaruh Komunikasi, Pelatihan dan Motivasi Terhadap Kinerja Pegawai Negeri Sipil Pada Badan Narkotika Nasional Provinsi Bengkulu”.

\section{B. LANDASAN TEORI}

\section{Kinerja Pegawai}

Kinerja seorang pegawai merupakan hal yang bersifat individual, karena setiap pegawai mempunyai tingkat kemampuan yang berbeda - beda dalam mengerjakan tugasnya. Pihak manajemen dapat mengukur kinerja kualifikasi para pegawai berdasarkan kinerja dari masing - masing pegawai itu sendiri. Kinerja terdiri dari banyak komponen dan bukan merupakan hasil yang dapat dilihat pada saat itu juga. Pada dasarnya kinerja merupakan sesuatu hal yang bersifat individual, karena setiap pegawai memiliki tingkat kemampuan yang berbeda dalam mengerjakan tugasnya. Kinerja tergantung pada kombinasi antara kemampuan, usaha, dan kesempatan yang diperoleh.

Whitmore memaparkan definisi kinerja sebagai pelaksanaan fungsifungsi yang dituntut dari seorang atau suatu perbuatan, suatu prestasi, suatu pameran umum keterampilan. Kinerja merupakan suatu kondisi yang harus diketahui dan dikonfirmasikan kepada pihak tertentu untuk mengetahui tingkat pencapaian hasil suatu instansi dihubungkan dengan visi yang diemban suatu organisasi atau perusahaan serta mengetahui dampak 
positif dan negatif dari suatu kebijakan operasional. ${ }^{6}$

Darma ${ }^{7}$ menyatakan bahwa bahwa faktor-faktor tingkat kinerja staf meliputi: mutu pekerjaan, jumlah pekerjaan, efektifitas biaya dan inisiatif. Sementara karakteristik individu yang mempengaruhi kinerja meliputi: umur, jenis kelamin, pendidikan, lama kerja, penempatan kerja dan lingkungan kerja (rekan kerja, atasan, organisasi, penghargaan dan imbalan).

Dessler ${ }^{8}$ menyatakan kinerja karyawan adalah prestasi aktual karyawan dibandingkan dengan prestasi yang diharapkan dari karyawan. Prestasi kerja yang diharapkan adalah prestasi standar yang disusun sebagai acuan sehingga dapat melihat kinerja karyawan sesuai dengan posisinya dibandingkan dengan standar yang dibuat. Selain itu dapat juga dilihat kinerja dari karyawan tersebut terhadap karyawan lainnya.
Multitama ${ }^{9}$ menyatakan kinerja menurut prespektif Islam merupakan bentuk atau cara individu dalam mengaktualisasikan diri. Kinerja merupakan bentuk nyata dari nilai, kepercayaan, dan pemahaman yang dianut serta dilandasi prinsip-prinsip moral yang kuat dan dapat menjadi motivasi untuk melahirkan karya bermutu.

Pada Kesempatan yang berbeda Al Ghazali, A.H.H (Directur Islamich Research and Training Institute) mengemukakan faktor-faktor yang mempengaruhi kinerja karyawan adalah sebagai berikut :
a. Motivasi
b. Pendidikan
c. Disiplin kerja
d. Keterampilan
e. Sikap Etika Kerja
f. Teknologi
g. Sarana produksi
h. Jaminan Sosial
i. Manajemen

Allah SWT berfirman dalam Al-Qur'an ${ }^{10}$ surat Al-Fath ayat 29 yang artinya :

Muhammad itu adalah utusan Allah dan orang-orang yang bersama dengan dia adalah keras

6 Whitmore, Enacting the Scholar Practitioner Role: An Exploration Narrative, Journal of Behavioral applied Science, 1997, hlm.5

${ }^{7}$ Darma Manajemen Sumberdaya Manusia. Edisi Ketiga, STIE, YKPN, Yogyakarta 2005, hlm.99

\footnotetext{
${ }^{8}$ Whitmore, Enacting the Scholar..., hlm. 5
}

9 Multitama, Islamic Business Strategy For Enterpreneurship, Zikrul Hakim, Jakarta, 2006, hlm. 85

10 Departemen Agama RI. Al-Qur'an dan terjemahan. Jakarta. 2010, Surat 48 
terhadap orang-orang kafir tetapi kasih saying sesame mereka; kamu lihat mereka ruku',dan sujud mencari karunia Allah dalam keridhaannya, tanda-tanda mereka tampak pada muka mereka dari bekas sujud. Demikian sifat-sifat mereka dalam taurat dan injil, yaitu seperti tanaman yang mengeluarkan tunasnya, maka tunas tersebut menjadi kuat lalu menjadi besar dan tegak lurus diatas pokoknya”.

\section{Komunikasi}

Henry ${ }^{11}$ mengemukakan bahwa komunikasi adalah suatu proses penyampaian informasi (pesan, ide, gagasan) dari satu pihak kepada pihak lain agar terjadi saling mempengaruhi diantar keduanya. Selanjutnya Hardjana, A.M menyatakan bahwa komunikasi adalah proses penyampaian makna dalam bentuk gagasan atau informasi dari seseorang kepada orang lain melalui media tertentu. Dalam kesempatan lain Purwanto, Djoko ${ }^{12}$ mendefinisikan komunikasi sebagai suatu proses pertukaran informasi antar individu melalui suatu sistem yang biasa (lazim) baik dengan simbol-simbol, sinyal-sinyal maupun perilaku atau

\footnotetext{
11 Henry, Manajemen Sumber Daya Manusia, Pustaka Setia, Bandung, 2013, hlm.61

${ }^{12}$ Purwanto, Djoko, Teori Komunikasi : Analisis dan Aplikasi, Salemba Humanika, Jakarta, 2006, hlm. 31
}

tindakan. Pada sisi lain, Koontz ${ }^{13}$ menyampaikan bahwa komunikasi adalah penyampaian atau pengiriman informasi dari seseorang kepada orang lain, sehingga informasi dapat dipahami oleh penerima.

Muis, Abdul ${ }^{14}$ mengemukakan bahwa semua macam komunikasi Islam pada dasarnya tidak berbeda dengan komunikasi non-Islam dalam hal model, proses dan efeknya, tetapi yang membedakannya lebih kepada landasan filosofisnya. Landasan filosofis komunikasi Islam ialah Al- Qur"an dan Hadis Nabi. Jadi komunikasi Islam adalah proses penyampaian pesan antar manusia didasarkan pada ajaran agama Islam yang terkandung dalam al-Qur"an dan Hadis

Handoko 15 mengemukakan pendapat bahwa tipe saluran-saluran dasar komunikasi adalah vertikal, horizontal dan diagonal.

a. Komunikasi Vertikal : Komunikasi vertikal terdiri atas komunikasi ke bawah dan komunikasi ke atas sesuai rantai perintah. Manajemen seharusnya tidak hanya memusatkan perhatiannya pada

13 Koontz, On High Performance Organization. Jakarta : Elexmedia Komputindo, 2004, hlm. 23

14 Muis, Abdul., Komunikasi Islami, Remaja Rosdakary, Bandung, hlm. 24

15 Handoko, Manajemen, Abdi Pustaka, Jakatra, 2001, hlm. 13 
komunikasi ke bawah, tetapi juga komunikasi ke atas.

b. Komunikasi Horizontal : Bentuk komunikasi ini pada dasarnya bersifat koordinatif dan merupakan hasil dari konsep spesialisasi organisasi. Sehingga komunikasi ini dirancang guna mempermudah koordinasi dan penanganan masalah. Komunikasi horizontal juga menghindarkan prosedur pemecahan masalah yang lambat.

c. Komunikasi Diagonal : Komunikasi diagonal merupakan komunikasi yang memotong secara menyilang diagonal rantai perintah organisasi. Hal ini sering terjadi sebagai hasilhasil hubungan departemen lini dan staf. Tipe komunikasi ini mencangkup masalah-masalah lini dan saran staf. Hubungan-hubungan yang ada antara personalia lini dan staf dapat berbeda-beda, yang akan membentuk beberapa komunikasi diagonal yang berbeda-beda pula.

Menurut Eugene, F. B. ${ }^{16}$ dalam komunikasi yang efektif perlu diingat langkah-langkah berikut :

a. Mempunyai gagasan yang jelas tentang pesan yang akan disampaikan.

16 Eugene, F. B., Manajemen Keuangan, Erlangga, Jakarta 2001,hlm. 27 b. Gagasan harus disampaikan dalam bentuk yang sesuai, bila mungkin dalam bahasa si penerima.

c. Memilih medium komunikasi yang paling sesuai, misalnya telepon/fax, e-mail, rapat/pertemuan, memo atau laporan.

d. Memastikan bahwa pesan sampai pada penerima, namun demikian harus disadari bahwa dalam analisis akhir tanggung jawab untuk mengartikan isi pesan ada pada penerima.

e. Memastikan bahwa makna yang dimaksud oleh pesan sampai ke tujuan, hal ini lebih mudah dalam komunikasi dua arah.

\section{Pelatihan}

Banyak penelitian yang mengkaji tentang faktor pengaruh dalam manajemen terhadap peningkatan kinerja karyawan, dan pelatihan adalah salah satu dari lima unsur pengaruh yang paling dominan seperti yang diungkapkan oleh Agrawal, Archana ${ }^{17}$ selain faktor kebebasan kerja, dukungan organisasi, perlindungan hukum dan penerapan hukum. Sebab pelatihan merupakan suatu upaya yang dilakukan oleh banyak perusahaan untuk

${ }^{17}$ Agrawal, Archana, Manajemen Sumber Daya Manusia, Ardana Media, Yogyakarta, 2013, hlm. 45 
meningkatkan kompetensi karyawan agar mereka dapat berkinerja tinggi.

Dalam Kesempatan yang sama Rivai, dkk ${ }^{18}$ mengemukakan pelatihan yang diberikan kepada karyawan merupakan proses untuk menambah pengetahuan dan keahlian tertentu serta sikap agar para pegawai semakin terampil dan mampu melaksanakan tanggung jawabnya dengan semakin baik, sesuai dengan tugas pokok dan fungsi masing - masing.

Berbagai macam penjelasan mengenai pengertian pelatihan dar beberapa ahli diantaranya yaitu penjelasan dari Wilson ${ }^{19}$ yang mengatakan bahwa, pelatihan adalah proses untuk mempertahankan atau memperbaiki keterampilan karyawan untuk menghasilkan pekerjaan yang efektif dan pelatihan ditekankan pada peningkatan kemampuan untuk melakukan pekerjaan yang spesifik pada saat ini. Sinambela, L.P ${ }^{20}$ menyatakan pelatihan adalah proses pembelajaran yang memungkinkan pegawai melaksanakan pekerjaan yang sekarang sesuai dengan standar.

18 Rivai, dkk, Manajemen Organisasi, PT. Alam Pustaka, Bandung, 2010, hlm. 39

19 Wilson, Metodologi Penelitian Bisnis Untuk Akuntansi dan Manajemen, Edisi Pertama, Cetakan Kedua, BPFE : Yogyakarta, 2010, hlm. 88

20 Sinambela, L.P, Managemen Prilaku Organisasi, Citra Aditya Bhakti, Bandung, 2012,hlm.12
Selanjtnya Mutiara ${ }^{21}$ juga menjelaskan bahwa pelatihan sebagai suatu cara yang digunakan untuk memberikan atau meningkatkan keterampilan yang dibutuhkan untuk melaksanakan pekerjaannya sekarang. Pendapat lain juga dijelaskan Mangkunegara ${ }^{22}$ bahwa pelatihan adalah suatu proses pendidikan jangka pendek yang mempergunakan prosedur sistematis dan terorganisir dimana karyawan non managerial mempelajari pengetahuan dan keterampilan teknis dalam tujuan terbatas

Irianto ${ }^{23}$ menyatakan bahwa secara konseptual programpelatihan melingkupi tiga tahapan, yaitu :

a. Analisa kebutuhan pelatihan.

b. Implementasi program pelatihan.

c. Evaluasi program pelatihan.

Rivai, dkk ${ }^{24}$ menyatakan bahwa pelatihan juga sebagai bagian pendidikan yang menyangkut proses belajar untuk memperoleh dan meningkatkan keterampilan di luar sistem pendidikan yang berlaku dalam waktu yang relatif singkat dengan

${ }^{21}$ Mutiara, Manajemen SDM buku 1, PT. Indo Jaya, Jakarta, 2004,hlm. 34

${ }^{22}$ Mangkunegara, Manajemen Sumber Daya Manusia Untuk Perusahaan, PT. Raja Grafindo Persada, Jakarta, 2006, hlm.21

23 Irianto, Manajemen. PT. Nada Satu, Jakarta, 2017, hlm. 73

24 Mangkunegara, Manajemen Sumber..., hlm. 21 
metode yang lebih mengutamakan pada praktik ke teori.

Wilson ${ }^{25}$ mengungkapkan bahwa tedapat empat proses pelatihan diantaranya yaitu :

a. Kebutuhan Pelatihan

Sebelum pelatihan ditetapkan maka hal yang terlebih dahulu dilakukan adalah diagnosis atas masalah-masalah pada kinerja karyawan. Setelah dilakukan identifikasi maka baru dilakukan perincian tujuan-tujuan yang harus dicapai. Di dalam analisis kebutuhan ada tiga sumber yang harus diperhatikan diantaranya adalah sebagai berikut :

1) Analisis organisasional yaitu proses untuk mendiagnosis kebutuhan-kebutuhan pelatihan dengan melakukan inventarisasi pengetahuan, keterampilan dan kemampuan karyawan pada masa sekarang untuk disesuaikan dengan masa akan datang.

2) Analisis pekerjaan yaitu membandingkan pengetahuan, keterampilan dan kemampuan karyawan dengan persyaratan pekerjaan.
3) Analisis individual yaitu mengidentifikasi kinerja individu dalam organisasi, memberikan pelatihan bagi individu yang memiliki kinerja rendah.

b. Perancangan Pelatihan

Setelah melakukan analisis kebutuhan hal yang perlu dilakukan selanjutnya adalah perancangan pelatihan. Dalam merancang pelatihan ada tiga hal yang diperhatikan diantaranya :

1) Kesiapan Peserta Pelatihan, meliputi motivasi, efektivitas diri, serta kemampuan mental dan fisik dalam mengikuti pelatihan.

2) Kemampuan Pelatih, dituntut untuk dapat menguasai materi pelatihan semaksimal mungkin agar para peseta dapat memperoleh pengetahuan dari materi yang disampaikan materi Pelatihan, harus sesuai dengan persyaratan pekerjaan, kemampuan peserta latihan, dan dibuat berdasarkan kebutuhan. Materi yang disampaikan pelatih harus mudah untuk dipahami oleh para peserta latihan.

c. Pelaksanaan Pelatihan

Setelah dilakukan perancangan

$$
{ }^{25} \mathrm{Ibid} \text {, }
$$


akan dilaksanakan pelatihan.

Berbagai faktor yang perlu diperhatikan agar hasil pelatihan efektif yaitu sifat pelatihan, identifikasi peserta latihan, kemampuan pelatih, lokasi geografis, biaya, waktu dan lamanya pelatihan. secara umum pelatihan dapat dilaksanakan di dalam dan luar organisasi serta pelatihan online melalui elearning. Penilaian pelatihan dilakukan untuk melihat hasil yang dicapai dengan membandingkan setelah dilakukan pelatihan dengan tujuan-tujuan yang diharapkan para manajer.

d. Penilaian Pelatihan

Penilaian pelatihan dilakukan untuk melihat hasil yang dicapai dengan membandingkan setelah dilakukan pelatihan dengan tujuantujuan yang diharapkan para manajer. Mengingat pelatihan membutuhkan waktu dan biaya yang besar, maka suatu pelatihan amat penting dilakukan penilaian.

\section{Motivasi}

Mangkunegara ${ }^{26}$ mengemukakan motivasi terbentuk dari sikap (attitute) karyawan dalam menghadapi situasi kerja di perusahaan (situation).

\footnotetext{
${ }^{26}$ Irianto, Manajemen..., hlm. 73
}

Motivasi merupakan kondisi atau energi yang menggerakkan diri karyawan yang terarah atau tertuju untuk mencapai tujuan organisasi perusahaan. Sikap mental karyawan yang pro dan positif terhadap situasi kerja itulah yang memperkuat motivasi kerjanya untuk mencapai kinerja maksimal. Pada kesempatan yang lain, Mangkunegara 27 mengemukan motivasi adalah dorongan yang muncul dalam diri seseorang baik karena faktor internal maupun eksternal yang menggerakannya untuk melakukan sesuatu demi mencapai tujuan.

Hal ini sesuai dengan pendapat Davis, Keith ${ }^{28}$ bahwa faktor yang mempengaruhi pencapaian kinerja adalah faktor kemampuan (ability) dan faktor motivasi (motivation). Sinambela, L.P 29 menyatakan peningkatan motivasi juga memiliki potensi dalam peningkatan pelatihan. Dalam hal ini terdapat hubungan yang signifikan antara motivasi kerja dengan pelatihan.

Motivasi berasal dari kata latin movere yang berarti dorongan, daya

\footnotetext{
${ }^{27}$ Ibid,.

${ }^{28}$ Davis, Keith, The Contribution of Total Quality Management to a Theory of Work performance, Academy of Management Review, 2006 ${ }^{29}$ Irianto, Manajemen..., hlm. 73
} 
penggerak atau kekuatan yang menyebabkan suatu tindakan atau perbuatan. Kata movere dalam bahasa inggris sering disepadankan dengan motivation yang berarti pemberian motif, penimbulan motif atau hal yang menimbulkan dorongan atau kesadaran yang menimbulkan dorongan.

Wilson ${ }^{30}$ mendefinisikan bahwa motivasi merupakan hasrat di dalam seseorang menyebabkan orang tersebut melakukan suatu tindakan.

Menurut Edwin B.F 31 mendefinisikan motivasi sebagai suatu keahlian, dalam mengarahkan pegawai dan organisasi agar mau bekerja secara berhasil, sehingga keinginan para pegawai dan tujuan organisasi sekaligus tercapai.

Manullang ${ }^{32}$ menyatakan bahwa motivasi adalah suatu dorongan yang memberikan daya rangsang kepada karyawan sehingga karyawan tersebut mampu untuk bekerja dengan segala daya dan upaya. Daya rangsang tersebut berupa kondisi mental yang mendorong dilakukannya suatu tindakan dan memberikan kekuatan yang mengarah kepada pencapain

${ }^{30}$ Ibid,.

31 Edwin B.F, Manajemen dan Evaluasi Kerja, Lembaga Penerbit FEUI, Jakarta, 2006, hlm.40

${ }^{32}$ Manullang, Manajemen Karyawan, CV. Buana Karya, Bogor, 2002, hlm.72 kebutuhan, memberikan kepuasan ataupun mengurangi

ketidakseimbangan.

Pada sisi lain Martoyo, Susilo ${ }^{33}$ mengemukakan pemdapatnya yaitu motivasi merupakan suatu pemberian dorongan sehingga mampu menciptakan suasana kerja yang harmonis yang diharapkan dapat membuat pegawai bekerja dengan lebih semangat sehingga kinerja para karyawan dapat lebih optimal lagi.

Sedangkan menurut Robbins dan Counter, Mary ${ }^{34}$ menyatakan bahwa motivasi kerja sebagai kesediaan untuk melaksanakan upaya tinggi untuk mencapai tujuan - tujuan keorganisasian yang dikondisikan oleh kemampuan upaya untuk memenuhi kebutuhan individual tertentu.

Pada sisi lain, motivasi disefinisikan sebagai dorongan yang sangat menentukan tingkah laku dan perbuatan manusia. Motivasi menjadi kunci utama dalam menafsirkan dan melahirkan perbuatan manusia. Peranan yang demikian menentukan ini, dalam konsep Islam disebut sebagai niyyah dan „Ibadah. Niyyah merupakan pendorong utama manusia untuk

\footnotetext{
${ }^{33}$ Martoyo,Susilo, Manajemen Sumberdaya, PT, Thamrin, Jakarta, 2011, hlm.87
} hlm.72 
berbuat atau beramal.Sementara

Ibadah adalah tujuan. ${ }^{35}$

Berdasarkan fenomena dan fakta

di Badan Narkotika Nasional Provinsi

Bengkulu, penulis tertarik untuk mengangkat penelitian dengan judul

"Pengaruh Komunikasi, Pelatihan dan

Motivasi Terhadap Kinerja Pegawai

Negeri Sipil Pada Badan Narkotika

Nasional Provinsi Bengkulu”.

\section{METODE PENELITIAN}

Penelitian ini menggunakan pendekatan deskriptif kuantitatif dengan kerangka teori para ahli kemudian untuk menjadi rujukan pemecahan permasalahan-permasalahan untuk memperoleh pembenaran (verifikasi) dalam bentuk dukungan data empiris di lapangan karena hasil penelitian ini difokuskan pada penggambaran kondisi lapangan mengenai kinerja pegawai pada Badan Narkotika Nasional Provinsi Bengkulu. Variabel penelitian yaitu komunikasi, pelatihan dan motivasi. Ketiga faktor tersebut akan diteliti pengaruhnya terhadap kinerja para pegawai pada Badan Narkotika Nasional Provinsi Bengkulu, untuk lebih jelasnya kerangka pemikiran tersebut divisualisaikan dalam skema berikut:

\section{Gambar 2. Variabel Independen (X) Variabel Dependen (Y)}

35 Baharuddin, Paradigma Psikologi Islami, Pustaka Pelajar, Yogyakarta, 2004, hlm.239

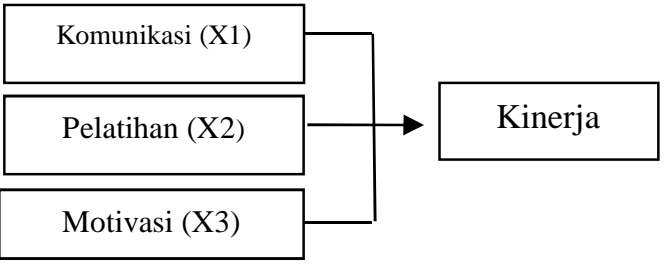

Berdasarkan masalah yang telah dirumuskan, penelitian ini menggunakan metode deskriptif kualitatif. Penelitian ini mengambil sample dari suatu populasi dan menggunakan kuisioner sebagai alat pengumpulan data. Penelitian dilakukan pada Badan Narkotika Nasional Provinsi Bengkulu. Jenis penelitian ini menggunakan pendekatan deskriptif kuantitatif, hasil yang diteliti difokuskan pada penggambaran kondisi lapangan mengenai kinerja pada Badan Narkotika Nasional Provinsi Bengkulu .

Metode pengumpulan data pada subyek penelitian ditentukan dengan menggunakan purposive sampling yaitu seluruh pegawai pada Badan Narkotika Nasional Provinsi Bengkulu 89 orang yang menjadi responden dalam penelitian.

Penelitian ini menggunakan metode deskriptif kuantitatif dengan menggunakan kuisioner dan obsrvasi sebagai alat pengumpulan data. Penelitian dilakukan pada Badan Narkotika Nasional Provinsi Bengkulu. Adapun pngolahan data dilakukan dengan mengunakan dengan pengolahan data mengguanakan software SPSS melalui uji statistik $\mathrm{F}$ untuk pengujian secara 
simultan dan uji statistik $\mathrm{t}$ untuk pengujian secara parsial serta penarikan kesimpulan dan verifikasi data.

\section{HASIL DAN PEMBAHASAN}

BNNP Bengkulu mempunyai tugas melaksanakan tugas, fungsi dan wewenang BNN dalam wilayah Provinsi Bengkulu. Fungsi BNNP Bengkulu :

1. Pelaksanaan koordinasi penyusunan rencana strategis dan rencana kerja tahunan di bidang pencegahan dan pemberantasan penyalahgunaan dan peredaran gelap narkotika, psikotropika, prekursor dan bahan adiktif lainnya kecuali bahan adiktif untuk tembakau dan alkohol yang selanjutnya disebut P4GN dalam wilayah Provinsi Bengkulu

2. Pelaksanaan kebijakan teknis di bidang pencegahan pemberdayaan masyarakat, rehabilitasi, dan pemberantasan dalam wilayah Provinsi Bengkulu

3. Pelaksanaan pembinaan teknis dan supervisi P4GN kepada BNNK/Kota dalam wilayah Provinsi Bengkulu

4. Pelaksanaan layanan hukum dan kerjasama dalam wilayah Provinsi Bengkulu

5. Pelaksanaan koordinasi dan kerja sama P4GN dengan instansi pemerintah terkait dan komponen masyarakat dalam wilayah Provinsi Bengkulu
6. Pelayanan administrasi BNNP Bengkulu

7. Pelaksanaan evaluasi dan pelaporan BNNP Bengkulu

Selanjutnya selain memiliki tugas BNNP juga memiliki kewenangan yaitu kewenangan dikhususkan oleh undangundang adalah tugas dalam melaksanakan Pemberantasan Penyalahgunaan dan Peredaran Gelap Narkoba dan Prekursor Narkotika, BNNP berwenang melakukan penyelidikan dan penyidikan di wilayah Provinsi dan berkoordinasi dengan BNN dan Kepolisian di daerah

Adapun visi Badan Narkotika Nasional Provinsi Bengkulu yaitu : "Menjadi Perwakilan Badan Narkotika Nasional di Provinsi Bengkulu secara Profesional yang Mampu Menyatukan dan Menggerakkan Seluruh Komponen Masyarakat Bengkulu dalam Melaksanakan P4GN".

Selanjutnya Misi dari Badan Narkotika Nasional Provinsi Bengkulu adalah bersama instansi pemerintah, komponen masyarkat serta instansi swasta di Provinsi Bengkulu melaksanakan :

1. Pencegahan

2. Pemberdayaan masyarakat

3. Penjangkauan dan pendampingan

4. Pemberantasan

5. Tata kelola pemerintahan yang akuntabel 
Hasil pengolahan data penelitian dengan menggunakan kuesioner terhadap responden pegawai Badan Narkotika Nasional Provinsi Bengkulu dengan menggunakan software SPSS 17 diperoleh model regresi sebagai berikut :

$$
\begin{array}{cccc}
Y=4.4 & +5.2 & X_{1}+9.2 & X_{2} \\
& +6.9 & X_{3}
\end{array}
$$

dimana,

$\mathrm{Y} \quad$ : Kinerja pegawai

$\mathrm{X}_{1} \quad$ : Komunikasi

$\mathrm{X}_{2}$ : Pelatihan

$\mathrm{X}_{3} \quad$ : Motivasi

Hal tersebut berindikasi bahwa komunikasi, pelatihan dan motivasi memberikan pengaruh yang terkait terhadap kinerja pegawai pada Badan Narkotika Nasional Provinsi Bengkulu .

\section{Uji statistik $F$}

Adapun hasil pengujian statistik F menggunakan software SPSS 17 terdapat nilai annova (uji statistik F) sebesar .923 dengan signifikansi .002 artinya terdapat pengaruh secara simultan antara komunikasi, pelatihan dan motivasi yang baik terhadap kinerja pegawai Badan Narkotika Nasional Provinsi Bengkulu.

Pada Badan Narkotika Nasional Provinsi Bengkulu, komunikasi sebagai media penyampaian informasi sangatlah penting untuk menunjang tugas Badan Narkotika Nasional sebagai vocal point untuk melakukan upaya Pencegahan, Pemberantasan Penyahgunaan dan Peredaran Gelap Narkoba. Selain itu, Pelatihan yang diberikan oleh Badan Narkotika Nasional Provinsi Bengkulu sangat menunjang peningkatan kinerja sehingga pegawai dapat berkerja lebih optimal. Selanjutnya motivasi yang diberikan atasan pada para pegawai Badan Narkotika Nasional Provinsi Bengkulu juga membawa dampak positif terhadap kinerja pegawai.

\section{Uji statistik t}

Pada penelitian Trijaya ${ }^{36}$ mengemukakan kompensasi, pelatihan, dan komunikasi berpengaruh signifikan terhadap kinerja karyawan dan yang menjadi variabel dominan adalah kompensasi. Selanjutnya penelitian Rachmadi ${ }^{37}$ menyimpulkan bahwa motivasi, partisipasi, dan komunikasi berpengaruh signifikan terhadap kinerja karyawan.

Adapun hasil penelitian dengan melalui uji statistik $\mathrm{t}$ menggunakan software SPSS 17 diperoleh nilai uji statistik $\mathrm{t}$ untuk pengaruh parsial antara komunikasi terhadap kinerja

${ }^{36}$ Trijaya, Pengaruh Kompensasi, Pelatihan, dan Komunikasi terhadap kinerja karyawan: Jurnal Ilmu Bisnis, 2012, hlm. 3

37 Rachmadi, Pengaruh Motivasi, Partisipasi, Dan Komunikasi terhadap kinerja karyawan. Jurnal EKIS, 2010, hlm. 4 
pegawai sebesar .731 dengan

signifikan sebesar .003.

Hal tersebut mengindikasikan bahwa komunikasi yang baik dan efektif dapat meningkatkan kinerja pegawai. Hasil penelitian ini memperkuat hasil penelitian sebelumnya bahwa komunikasi memberikan kontibusi positif terhadap kinerja pegawai.

Komunikasi yang menjadi sarana penyampaian komunikasi terus dibangun pada Badan Narkotika Nasional misalnya dengan mengadakan apel pagi sebagai sarana penyampaian informasi harian dan juga membentuk media grup komunikasi dalam hal ini grup whats up sehingga apabila ada informasi dapat diterima secara tepat dan akurat. Pada sisi lain, Badan Narkotika Nasional Provinsi Bengkulu juga melakukann koordinasi dengan berbagai lemabaga pemerintah lainnya guna meningkatkan kolaborasi agar terciptanya sinergitas program kerja.

Penelitian

Sudarso, Eddy ${ }^{38}$ mengemukakan bahwa terdapat hubungan yang signifikan antara motivasi dan pelatihan dengan kinerja karyawan perusahaan rokok PT. HM.

${ }^{38}$ Sudarso, Eddy, Pengaruh Motivasi dan pelatihan dengan kinerja karyawan perusahaan rokok PT. HM. Sampoerna Tbk Malang, Jurnal Ekonomi dan Bisnis, 2008, hlm. 7
Sampoerna Tbk Malang. Demikian juga Ali ${ }^{39}$, hasil penelitiannya menunjukkan bahwa pendidikan pelatihan, pengetahuan, sikap dan ketrampilan secara bersama-sama berpengaruh positif signifikan terhadap kinerja Pegawai Administrasi Universitas Islam Negeri Sultan Syarif Kasim Riau

Berdasarkan hasil penelitian yang dilakukan diperoleh terdapat pengaruh parsial antara pelatihan terhadap kinerja pegawai sebesar 2.435 dengan signifikan sebesar .004.

Hal tersebut berindikasi bahwa pelatihan yang diberikan kepada pegawai berbanding lurus dengan kinerja pegawai sehingga dapat disimpulkan bahwa hasil penelitian ini membrnarkan peelitian sebelumnya bahwa semakin banyak pelatihan yang diberikan kepada pegawai bekerja maka kinerja yang dihasilkan juga akan maksimal.

Pada Badan Narkotika Nasional Provinsi Bengkulu, berbagai macam pelatihan telah diterima oleh pegawai Badan Narkotika Nasional Provinsi Bengkulu misalnya pelatihan untuk aplikator SIMPEG, aplikator SIMAK, Pelatihan asesor dan lainnya. Setelah

${ }^{39}$ Ali, Pengaruh pelatihan, pengetahuan dan ketrampilan terhadap kinerja Pegawai Administrasi Universitas Islam Negeri Sultan Syarif Kasim Riau, Jurnal Ekonomi, 2008, hlm. 2 
pegawai menerima pelatihan tersebut para pegawai dapat melaksanakan tugas sesuai dengan SOP yang telah ditentukan sehingga memperoleh hasil kerja yang maksimal.

Penelitian yang dilakukan oleh Listianto ${ }^{40}$ menyatakan bahwa motivasi kerja berpengaruh positif dan signifikan terhadap kinerja karyawan. Selain itu juga penelitian yang dilakukan oleh Prasetyo dan Wahyuddin ${ }^{41}$ mendukung penelitian sebelumnya yang menyatakan bahwa motivasi berpengaruh positif dan signifikan terhadap kinerja karyawan, dan dalam mempengaruhi kinerja karyawan.

Berdasarkan hasil penelitian yang dilakukan menunjukkan pengaruh parsial antara motovasi terhadap kinerja pegawai sebesar .356 dengan signifikan sebesar .002.

Hal tersebut menunjukkan hubungan antara motivasi dan kinerja berbanding lurus, artinya Hasil penelitian ini menegasakan hasil penelitian sebelumnya bahwa semakin tinggi motivasi karyawan dalam

${ }^{40}$ Listianto, Pengaruh Motivasi, Kepuasan, Dan Disiplin Kerja Terhadap Kinerja Karyawan (Studi Kasus di Lingkungan Pegawai Kantor PDAM Kota Surakarta) Jurnal Manajemen, 2007, hlm. 5

41 Wahyuddin, Pengaruh Faktor-faktor Kepuasan Kerja Terhadap Kinerja Karyawan Pusat Pendidikan Komputer AkuntansiIMKA di Surakarta. Program Pascasarjana Universitas Muhammadiyah Surakarta. Solo, 2007 bekerja maka kinerja yang dihasilkan juga tinggi.

Pada Badan Narkotika Nasional Provinsi Bengkulu, para atasan selalu memberikan motivasi bawahan misalnya dengan memberikan reward bagi pegawai yang memiliki kompetensi unggul dalam menyelesaikan tugasnya. Hal tersebut membuat para pegawai berlomba dalam mengembangkan potensi untuk meningkatkan kinerjanya.

Berdasarkan hasil uji statisti t di atas diperoleh kesimpulan bahwa adanya pengaruh parsial yang signifikan antara pelatihan terhadap kinerja pegawai Badan Narkotika Nasional Provinsi Bengkulu.

\section{E. KESIMPULAN}

Berdasarkan hasil penelitian yang telah dikemukakan maka diperoleh kesimpulan antara lain sebagai berikut :

1. Perlu diperluas lagi yang menjadi target dalam kegiatan Focus Discussion Group yang diselenggarakan oleh Badan Narkotika Nasional Provinsi Bengkulu dari segala lini karena dapat kinerja pegawai Badan Narkotika Nasional Provinsi Bengkulu sebagai vocal point dalam upaya Pencegahan, Pemberantasan Penyalah gunaan dan Peredaran Gepak Narkoba di kawasan Provinsi Bengkulu 
2. Dalam upaya peningkatkan kinerja para pegawai hendaknya Badan Narkotika Nasional Provinsi Bengkulu memberikan pelatihan secara internal mengenai cara mengoperasikan komputer kepada para pegawai yang belum memiliki kompetensi.

3. Perlu dilakukan upaya peningkatan motivasi para pegawai Badan Narkotika Nasional Provinsi Bengkulu yang merasa sulit dan belum mampu mengoperasikan computer, mengingat Badan Narkotika Nasional Provinsi Bengkulu sudah mengadopsi basis kompitesisasi dan teknologi informasi sebagai upaya sinkronisasi program kerja pusat dan daerah.

\section{DAFTAR PUSTAKA}

Agrawal, Archana.2013. Manajemen Sumber Daya Manusia, Yogyakarta : Ardana Media

Counter, Mary.1999. Research Methods For Business. New York. John Willey \& Sons, Inc

Ali (2008). Pengaruh pelatihan, pengetahuan dan ketrampilan terhadap kinerja Pegawai Administrasi Universitas Islam Negeri Sultan Syarif Kasim Riau: Jurnal Ekonomi. 2(4)

Darma. 2005. Manajemen Sumberdaya Manusia. Edisi Ketiga. Yogyakarta: STIE, YKPN

Davis, Keith. 2006. The Contribution of Total Quality Management to a
Theory of Work performance, Academy of Management Review

Departemen Agama RI. Al-Qur'an dan terjemahan. Jakarta. 2010

Dessler.2010. Manajemen Sumber Daya Manusia. Alih bahasa: Eli Tanya. Penyunting Bahasa: Budi Supriyanto. Jakarta: Indeks

Edwin B.F. 2006. Manajemen dan Evaluasi Kerja. Lembaga Penerbit FEUI, Jakarta.

Eugene, F. B. 2001. Manajemen Keuangan. Jakarta: Erlangga.

Handoko (2001). Manajemen. Jakatra: Abdi Pustaka

Hardjana, A.M (2007). , Manajemen Sumber Daya Manusia. Bandung: CV. Taraluya Pustaka

Henry (2013). Manajemen Sumber Daya Manusia. Bandung Pustaka Setia

Irianto (2017). Manajemen. Jakarta: PT. Nada Satu

Koontz (2004). On High Performance Organization. Jakarta : Elexmedia Komputindo

Listianto (2007). Pengaruh Motivasi, Kepuasan, Dan Disiplin Kerja Terhadap Kinerja Karyawan (Studi Kasus di Lingkungan Pegawai Kantor PDAM Kota Surakarta): Jurnal Manajemen 5 (3)

Martoyo, Susilo (2011). Manajemen Organisasi. Bandung PT. Pasir Biru

Mangkunegara (2006). Manajemen Sumber Daya Manusia Untuk Perusahaan. Jakarta: PT. Raja Grafindo Persada

Mangkunegara (2011). Manajemen. Jakarta: CV. Angkasa Raya

Manullang (2002). Manajemen Karyawan. Bogor : CV. Buana Karya

Martoyo,Susilo (2011) Manajemen Sumberdaya. Jakarta : PT, Thamrin 
Mutiara (2004). Manajemen SDM buku 1. Jakarta : PT. Indo Jaya

Muis, Abdul, 2001, Komunikasi Islam, Bandung: Remaja Rosdakarya

Multitama, 2006, Islamic Business Strategy For Enterpreneurship , Jakarta: Zikrul Hakim

Peraturan Kepala BNN Nomor 6 Tahun 2015 tentang Perubahan atas Peraturan Kepala Badan Narkotika Nasional Nomor 3 Tahun 2015 tentang Organisasi dan Tata Kerja Badan Narkotika Nasional Provinsi dan Badan Narkotika Nasional Kabupaten/Kota

Purwanto, Djoko (2006). Teori Komunikasi : Analisis dan Aplikasi. Jakarta: Salemba Humanika

Rachmadi (2010) Pengaruh Motivasi, Partisipasi, Dan Komunikasi terhadap kinerja karyawan. Jurnal EKIS 4(2)

Rivai, dkk (2010). Manajemen Organisasi. Bandung : PT. Alam Pustaka

Robbins,Stephen. 1996. Perilaku Organisasi Jilid II, Alih Bahasa Hadayana Pujaatmaka. Jakarta: Prenhalindo

Robbins., Counter, Mary (1999). "Development of Managerial performance: A Research approach".
Cincinnati. OH: Southwestern publishing Co

Septiana (2018). Manajemen Pemasaran.Bandung : CV. Setia Budi

Sudarso, Eddy (2008). Pengaruh Motivasi dan pelatihan dengan kinerja karyawan perusahaan rokok PT. HM. Sampoerna Tbk Malang: Jurnal Ekonomi dan Bisnis. 7 (1).

Sinambela, L.P (2012). Managemen Prilaku Organisasi, Bandung: PT. Citra Aditya Bhakti.

Trijaya (2012) Pengaruh Kompensasi, Pelatihan, dan Komunikasi terhadap kinerja karyawan: Jurnal Ilmu Bisnis 3(5)

Wahyuddin (2007). Pengaruh Faktor-faktor Kepuasan Kerja Terhadap Kinerja Karyawan Pusat Pendidikan Komputer AkuntansiIMKA di Surakarta. Program Pascasarjana Universitas Muhammadiyah Surakarta. Solo.

Whitmore (1997). Enacting the Scholar Practitioner Role: An Exploration Narrative. Journal of Behavioral applied Science

Wilson (2012). Metodologi Penelitian Bisnis Untuk Akuntansi dan Manajemen, Edisi Pertama, Cetakan Kedua, BPFE : Yogyakarta 